\title{
PENGARUH KONSENTRASI RAGI DAN WAKTU FERMENTASI PADA PEMBUATAN BIOETANOL DARI BIJI CEMPEDAK (Artocarpus champeden spreng)
}

\author{
Irvan, Ayu Wandira Putri*, Sri Ulina Surbakti, Bambang Trisakti \\ Departemen Teknik Kimia, Fakultas Teknik, Universitas Sumatera Utara \\ Jl. Almamater Kampus USU Medan, 20155 Indonesia \\ *Email: Ayuwandiraputri13@gmail.com
}

\begin{abstract}
Abstrak
Kebutuhan bahan bakar minyak sebagai sumber energi setiap harinya semakin meningkat, sedangkan cadangan energi minyak bumi (fosil) semakin menipis, oleh karena itu, untuk memenuhi kebutuhan bahan bakar maka perlu dikembangkan bahan bakar alternatif yang sifatnya dapat diberbaharui dan rumah lingkungan (renewable). Salah satunya adalah bioetanol yaitu etanol yang terbuat dari tanaman yang mengandung pati, gula dan tanaman berselulosa lainnya. Penelitian ini bertujuan untuk membuat bioetanol dari biji cempedak dengan variasi konsentrasi ragi dan lama fermentasi. Proses utamanya adalah hidrolisis fermentasi menggunakan ragi Saccharomyces Cereviciae dan pemurnian dengan destilasi. Variabel yang digunakan adalah perubahan konsentrasi ragi 3\%, 6\%, 9\% dan lama fermentasi 2 hari, 3 hari, 4 hari. Dari analisis yang dilakukan terhadap hasil penelitian didapat perolehan bioetanol per jumlah bahan baku awal yang terbaik adalah $12,5 \mathrm{ml} / \mathrm{kg}$ dengan densitas sebesar $0,962 \mathrm{~g} / \mathrm{ml}$ dan nilai kalor sebasar $181,925 \mathrm{kkal} / \mathrm{kg}$, yaitu pada variasi konsentrasi ragi $9 \%$ dan lama fermentasi 3 hari.
\end{abstract}

Kata kunci : biji cempedak, bioetanol, fermentasi, ragi tape

\begin{abstract}
Needs fuel as a source of energy every day is increasing, while the energy reserves of petroleum (fossil) dwindling, therefore, to meet the needs of the fuel it is necessary to develop alternative fuels that are renewable and home environment (renewable ). Etonal Bioethanol is made from plants containing starch, sugar and other plant cellulose. Where in this study using jackfruit seeds that contain high enough carbohydrates as raw materials. This research aims to make bioethanol from cempedak seeds with various concentrations of yeast and fermentation time. The main process is hydrolysis; fermentation using yeast Saccharomyces Cereviciae; and purification by distillation and condensation. Variables used are changes in the concentration of yeast $3 \%, 6 \%$, $9 \%$ and 2 days, 3 days, 4 days fermentation period. From the analysis of the research results obtained bioethanol yield per amount of raw materials is the best starting $12,5 \mathrm{ml} / \mathrm{kg}$ with a density of $0.962 \mathrm{~g} / \mathrm{ml}$ and the calorific value sebasar $181.925 \mathrm{kcal} / \mathrm{kg}$, which is the variation of the concentration of $9 \%$ and 3 days of fermentation period.
\end{abstract}

Keywords : ethanol, cempedak seeds, tape yeast, fermentation

\section{Pendahuluan}

Diperkirakan konsumsi bahan bakar minyak dunia pada tahun 2025-2030 sekitar 190 juta barrel per hari, atau dua kali lipat dari konsumsi BBM saat ini. Indonesia merupakan salah satu negara yang sedang menghadapi persoalan energi yang serius akibat ketergantungan yang sangat besar terhadap energi fosil. Padahal minyak bumi merupakan bahan bakar yang tidak dapat diperbaharui (non-renewable). Oleh karena itu, untuk memenuhi kebutuhan bahan bakar maka perlu dikembangkan bahan bakar alternatif yang sifatnya dapat diperbaharui dan ramah lingkungan (renewable [10].

Salah satu alternatif yang potensial untuk dikembangkan adalah penggunaan bioetanol. Bioetanol adalah bahan bakar alternatif yang diolah dari tumbuhan (biomassa) dengan cara fermentasi, dimana sumber bioetanol dari bahan berpati (amilum), bahan bergula, dan bahan berselulosa [8].

\section{Teori}

Cempedak (Artocarpus integer), merupakan komoditas perkebunan yang memiliki prospek cerah dimasa yang akan datang, karena disamping dapat dimanfaatkan sebagai bahan pangan, juga dapat diproyeksikan sebahan bahan industri. Cempedak adalah buah multimanfaat yaitu daging buah yang dapat dikonsumsi dan biji 
yang dimanfaatkan menjadi bioetanol. Biji cempedak memiliki kandungan karbohidrat yang cukup tinggi yaitu sumber karbohidrat (36,7 $\mathrm{g} / 100 \mathrm{~g})$, yang jumlahnya tiga kali lipat jumlah biji gandum. Protein biji cempedak (4,2 g/100 g) hampir melebihi setengah dari kandungan gandum.

Melimpahnya biji cempedak berpotensi untuk dimanfaatkan sebagai bioethanol pengganti bahan bakar minyak (BBM) [4]. Bioetanol merupakan etanol yang diproduksi dari sumber bahan baku biologis, dimana memiliki keunggulan mampu menurunkan emisi gas $\mathrm{CO}_{2}$ hingga $18 \%$. Generasi pertama bioetanol dibuat dari sumber hasil perkebunan seperti jagung, ketela, dan kentang dengan melakukan pretreatment, hidrolisis dan kemudian fermentasi untuk mendapatkan etanol [9].

Etanol menurut tipenya terbagi dua, yaitu etanol sintesis yang berasal dari minyak bumi, dan bioetanol yang berasal dari biomassa (tanaman). Etanol sintesis $\left(\mathrm{C}_{2} \mathrm{H}_{5} \mathrm{OH}\right)$ sering disebut metanol atau etil alkohol, terbuat dari etilen, salah satu derivat minyak bumi atau batu bara. Bahan ini diperoleh dari proses sintesa kimia yang disebut hidrasi, sedangkan bioetanol direkayasa dari biomassa (tanaman) melalui proses biologi (fermentasi) bahan baku yang digunakan bisa dari bahan berpati, gula, selulosa, termasuk biomassa berselulosa yang merupakan sumber daya alam yang melimpah dan murah serta memiliki potensi untuk produksi komersial industri etanol atau butanol [14] Bioetanol memiliki cairan bewarna jenih, berbau khas alkohol, berfasa cair pada temperatur kamar, mudah terbakar, melalui proses sintesa kimia. Bahan baku bioetanol sebagai berikut:

a. Bahan berpati, berupa singkong atau ubi kayu, ubi jalar, tepung sagu, biji jagung dan biji durian.

b. Bahan bergula, berupa molasses (tetesan tebu), nira tebu, nira kelapa, nira batang sorgum manis.

c. Bahan berselulosa, berupa limbah logging, limbah pertanian seperti jerami padi, ampas tebu, tongkol jagung, onggok, batang pisang dan serbuk gergaji.

Saccharomyces cerevisiae merupakan khamir sejati tergolong eukariot yang secara morfologi hanya membentuk blastopora berbentuk bulat lonjong, silendris, oval atau bulat telur yang diri melalui pertunasan. Dalam fermentasi ini digunakan khamir Saccharomyces cerevisiae untuk menghasilkan glukosa. Pada penelitian ini,mikroba yang digunakan adalah ragi Saccharomyces cervisiae. Mikroba ini mampu mengkonversi selulosa dan hemiselulosa berantai karbon 5 menjadi bioetanol. Proses pembuatannya dapat dibedakan berdasarkan zat pembantu yang dipergunakan, yaitu Hydrolisa asam dan Hydrolisa enzyme. Ada 4 fase kurva pertumbuhan mikroorganisme yaitu fase lag/adaptasi, fase $\log$ /pertumbuhan eksponensial, fase kematian [15]. Secara kimiawi reaksi dalam proses fermentasi berjalan cukup panjang karena terjadi suatu deret reaksi yang masing-masing dipengaruhi oleh enzim. Masing-masing bahan berbeda cara pengolahannya untuk bisa dijadikan bioetanol, pengklasifikasian berdasarkan bahan baku yang digunakan, proses, dan pemanfaatannya [2].

Etanol memiliki banyak manfaat bagi masyarakat karena memiliki sifat yang tidak beracun. Selain itu, etanol juga memiliki banyak sifat-sifat, baik secara fisika maupun kimia. Adapun sifat-sifat fisika etanol dapat dilihat pada tabel 1 .

Tabel 1. Sifat-Sifat Fisika Etanol [11]

\begin{tabular}{|l|l|}
\hline Sifat Fisik Bioetanol & Keterangan \\
\hline Rumus Molekul & $\mathrm{CH}_{3} \mathrm{CH}_{2} \mathrm{OH}$ \\
Titik Beku & $-114,1^{0} \mathrm{C}$ \\
Berat Molekul & $46,07 \mathrm{~g} / \mathrm{g}$ mol \\
Titik Didih & $78,4^{0} \mathrm{C}$ \\
Densitas & $0,7893 \mathrm{~g} / \mathrm{ml}$ \\
Indeks Bias & $1,36143 \mathrm{cP}$ \\
Warna Cairan & Tidak bewarna \\
Aroma & Khas \\
Titik Lebur & $-112^{\circ} \mathrm{C}$ \\
\hline
\end{tabular}

Proses fermentasi sama dengan $\mathrm{pH}$ optimum untuk proses pertumbuhan khamir yaitu $\mathrm{pH}$ 4,0-4,5. Etanol dihasilkan dari gula yang merupakan hasil aktifitas fermentasi sel khamir. Kriteria pemilihan khamir untuk produksi etanol adalah mempunyai laju fermentasi dan laju pertumbuhan cepat, perolehan etanol banyak, tahan terdapat konsentrasi etanol dan glukosa tinggi, tahan terhadap konsentrasi garam tinggi, $\mathrm{pH}$ optimum serta fermentasi rendah [2].

\section{Metodologi Penelitian}

Bahan utama yang digunakan pada penelitian adalah tepung biji cempedak.

\section{Persiapan Bahan Baku (pretreatment)}

Biji cempedak disortir, dipilih yang bagus kemudian dicuci bersih. Setelah bersih biji 
cempedak dikeringkan dibawah sinar matahari \pm 2 hari dan pisahkan antara kulit ari dan biji cempedak. Biji tersebut dihancurkan dengan menggunakan blender menjadi berbentuk powder dengan ayakan 50 mess. Tepung bici cempedak lalu disimpan dalam wadah plastik yang kedap udara agar bahan baku tidak terkontaminasi [7].

\section{Tahap Persiapan Bahan Fermentasi}

Sampel biji cempedak yang sudah melewati tahap pretreatment dicampur dengan aquadest dengan berat tepung biji cempedak sebesar 100 g. Kemudian dihidrolisis dengan $\mathrm{H}_{2} \mathrm{SO}_{4}$ dan suhu 93-95 ${ }^{\circ} \mathrm{C}$ selama 30 menit hingga menjadi terbentuk slurry. Setelah proses hidrolisis selesai, bahan didingan hingga suhu kamar dengan cara memasukkan sampel didalam beaker glass ke dalam ember yang berisi air keran hingga suhunya turun [7].

\section{Tahap Fermentasi}

Hasil hidrolisis dimasukkan kedalam tempat fermentasi dan ditambahkan ragi sebanyak 3, 6, 9\% per bahan baku awal. Fermentasi dilakukan pada suhu ruangan selama 2, 3, 4 hari dalam keadaan anaerob [9].

\section{Proses Destilasi}

Hasil fermentasi lalu dimurnikan melalui proses destilasi pada suhu 70-80 ${ }^{\circ} \mathrm{C}$ dengan menggunakan peralatan destilasi. Sisa hasil destilasi disaring dan diambil padatannya. Sedangkan destilat ditampung lalu diukur volume destilat, dan kadar bioetanol yang diperoleh.

\section{Prosedur Analisa}

a. Penentuan Jumlah Bioetanol $(\mathrm{ml})$

1. Destilat hasil destilasi yang ditampung (bioetanol) diukur dengan menggunakan gelas ukur [7].

2. Volume dicatat untuk tiap-tiap perlakuan.

b. Penentuan Densitas Bioetanol $(\mathrm{g} / \mathrm{ml})$

1. Periksa keadaan alat lalu disambungkan dengan arus listrik.

2. Piknometer ditimbang dalam timbangan digital dan dicatat sebagai berat pikno kosong.

3. Kemudian piknometer diisi dengan sampel bioetanol hingga penuh kemudian timbang kembali dan dicatat sebagai berat pikno berisi.

\section{c. Prosedur Analisa Spesific Gravity dan Gravity}

Specific gravity dan API gravity adalah suatu pernyataan yang menyatakan densitas (kerapatan) atau berat per satuan volume dari suatu bahan. Hubungan antara specific gravity (sg) dan API gravity (G) dengan rumus (1) dan (2) sebagai berikut:

$$
\begin{gathered}
\mathrm{G}=\frac{141,5}{\mathrm{sg}}-131,5 \\
\mathrm{sg}=\frac{141,5}{\mathrm{G}+131,5}
\end{gathered}
$$

Besarnya harga dari API gravity berkisar dari 0-100, sedangkan specific gravity merupakan harga relatif dari densitas suatu bahan terhadap air.

\section{d. Analisis Kadar Bioetanol dengan Metode Berat Jenis}

Kadar etanol dihitung dengan menginterpolasi data densitas dan kadar etanol pada tabel 2 .

Tabel 2. Konversi Berat Jenis - Kadar Etanol

\begin{tabular}{|c|c|c|c|}
\hline $\begin{array}{l}\text { Kadar } \\
\text { Etanol }\end{array}$ & $\begin{array}{c}\text { Etanol } \\
\left(\text { Suhu } \quad \mathbf{3 0}^{\circ} \mathrm{C}\right)\end{array}$ & $\begin{array}{l}\text { Kadar } \\
\text { Etanol }\end{array}$ & $\begin{array}{l}\text { Berat } \\
\text { Jenis } \\
\text { Larutan }\end{array}$ \\
\hline 0 & 0,99568 & 25 & 0,95607 \\
\hline 1 & 0,99379 & 26 & 0,95442 \\
\hline 2 & 0,99194 & 27 & 0,95272 \\
\hline 3 & 0,99014 & 28 & 0,95098 \\
\hline 4 & 0,98839 & 29 & 0,94922 \\
\hline 5 & 0,98670 & 30 & 0,94741 \\
\hline 6 & 0,98507 & 31 & 0,94557 \\
\hline 7 & 0,98347 & 32 & 0,94370 \\
\hline 8 & 0,98189 & 33 & 0,94180 \\
\hline 9 & 0,98031 & 34 & 0,93986 \\
\hline 10 & 0,97875 & 35 & 0,93790 \\
\hline 11 & 0,97723 & 36 & 0,93591 \\
\hline 12 & 0,97573 & 37 & 0,93390 \\
\hline 13 & 0,97424 & 38 & 0,93186 \\
\hline 14 & 0,97278 & 39 & 0,92979 \\
\hline 15 & 0,97133 & 40 & 0,92770 \\
\hline 16 & 0,96990 & 41 & 0,92558 \\
\hline 17 & 0,96844 & 42 & 0,92344 \\
\hline 18 & 0,96697 & 43 & 0,92128 \\
\hline 19 & 0,96547 & 44 & 0,91910 \\
\hline 20 & 0,96395 & 45 & 0,91692 \\
\hline 21 & 0,96242 & 46 & 0,91472 \\
\hline 22 & 0,96087 & 47 & 0,91250 \\
\hline 23 & 0,95929 & 48 & 0,91028 \\
\hline 24 & 0,95769 & 49 & 0,90805 \\
\hline
\end{tabular}
[5]

e. Menghitung Nilai Kalor $(\mathrm{NK})$

Nilai kalor yang diperoleh dicatat untuk tiaptiap perlakuan [5].

f. Pengujian Indeks Bias

1. Keadaan alat diperiksa lalu disambungkan dengan arus listrik. 
2. Bioetanol ditetesi diatas kaca pada alat, kemudian diatur putaran agar tepat pada garis perpotongan. Dicatat hasil indeks biasnya.

3. Percobaan yang sama dilakukan dengan sampel yang berbeda

\section{Hasil dan Pembahasan}

Pengaruh Jumlah Ragi dan Waktu Fermentasi Terhadap Indeks Bias Bioetanol.

Gambar 1 memperlihatkan pengaruh konsentrasi ragi dan waktu fermentasi terhadap indeks bias bioetanol pada pembuataan bioetanol dari biji cempedak.

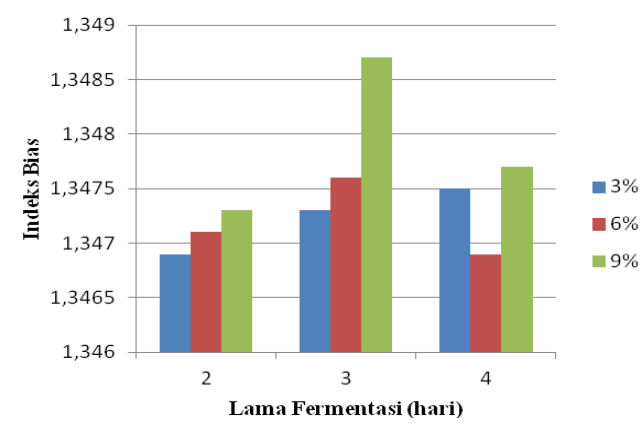

Gambar 1. Pengaruh Jumlah Ragi dan Waktu Fermentasi Terhadap Indeks Bias Bioetanol

Dapat dilihat pada gambar 1, bahwa lama fermentasi dan konsentrasi ragi mempengaruhi perolehan nilai indeks bias, dimana semakin lama fermentasi dan semakin tinggi konsentrasi ragi, maka indeks bias bioetanol meningkat sampai batas tertentu dan kemudian menurun.

Pengaruh Lama Fermentasi Terhadap Perolehan Volume Bioetanol.

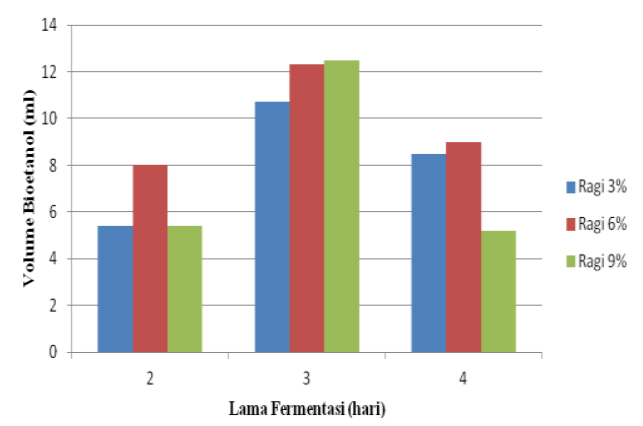

Gambar 2. Pengaruh Lama Fermentasi (hari) Terhadap Perolehan Volume Bioetanol
Dapat dilihat pada gambar 2, bahwa untuk semua konsentrasi ragi, perolehan volume bioetanol yang diperoleh meningkat yaitu lama fermentasi 2 hari ke 3 hari, kemudian menurun pada variasi lama fermentasi 4 hari. Jadi, volume tertinggi yang dihasilkan untuk semua variasi konsentrasi ragi fermentasi adalah pada lama fermentasi 3 hari. Dari gambar diatas dapat dilihat bahwa lama fermentasi mempengaruhi perolehan bioetanol, dimana semakin lama fermentasi dilakukan, volume yang diperoleh semakin meningkat sampai batas waktu tertentu dan kemudian menurun.

Pengaruh Konsentrasi Ragi dan Waktu Fermentasi Terhadap Densitas Bioetanol.

Gambar 3 memperlihatkan pengaruh konsentrasi ragi dan waktu fermentasi terhadap densitas bioetanol dari biji cempedak.

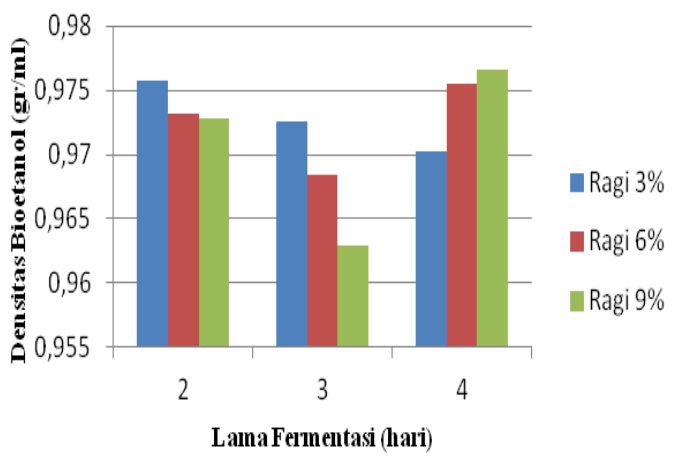

Gambar 3. Pengaruh Konsentrasi Ragi dan Waktu Fermentasi Terhadap Densitas Bioetanol Dari Biji Cempedak.

Gambar 3 memperlihatkan densitas bioetanol diperoleh $0,962 \mathrm{~g} / \mathrm{ml}$ dimana densitas tersebut melebihi dari densitas bioetanol absolut yaitu sebesar 0,789 g/ml [12]. Etanol yang dihasilkan masih belum murni karena bercampur dengan air. Hal ini disebabkan oleh distilasi yang dilakukan hanya distilasi sederhana bukan distilasi azeotrop serta kurang telitinya dalam menjaga kestabilan temperatur pada proses distilasi sehingga uap yang keluar bukan hanya bioetanol melainkan bercampur dengan air.

Pengaruh Konsentrasi Ragi dan Waktu Fermentasi Terhadap Spesifik Grafity.

Specific gravity dan API gravity adalah suatu pernyataan yang menyatakan densitas (kerapatan) atau berat per satuan volume dari suatu bahan, Besarnya harga dari spesific gravity maksimal 0,99968, dan specific gravity 
merupakan harga relatif dari densitas suatu bahan terhadap air.

Gambar 4 memperlihatkan pengaruh lama fermentasi terhadap spesific grafity bioetanol [1]. Gambar 4 memperlihatkan spesific grafity bioetanol diperoleh 0,9118 - 0,9472 dimana spesific grafity tersebut telah sesuai dari spesific grafity bioetanol absolut yaitu maksimal 0,99968 [5]. Etanol yang dihasilkan masih belum murni karena bercampur dengan air karena nilai spesific grafity masih terlalu tinggi.

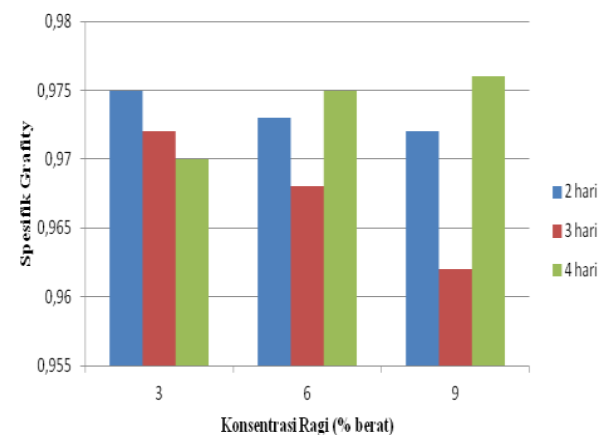

Gambar 4. Pengaruh Konsentrasi Ragi dan Waktu Fermentasi Terhadap Spesifik Grafity

\section{Volume Bioetanol Murni}

Kemurnian bioetanol dipengaruhi oleh pemurnian yaitu destilasi, etanol mendidih pada suhu $70-75^{\circ} \mathrm{C}$ etanol berubah dari cair menjadi uap. Volume bioetanol murni dapat dihitung dengan perkalian volume bioetanol yang didapat dengan \% kemurnian [7]. Hasil volume bioetanol murni dapat dilihat pada Tabel 3:

Tabel 3. Pengaruh Konsentrasi Ragi dan Waktu Fermentasi Terhadap Volume Bioetanol

\begin{tabular}{|c|c|c|c|l|c|}
\hline Hari & $\begin{array}{c}\text { Ragi } \\
(\boldsymbol{\%})\end{array}$ & $\begin{array}{c}\text { Volume } \\
\text { Peroleh } \\
(\mathbf{m l})\end{array}$ & $\begin{array}{c}\text { \% } \\
\text { Murni }\end{array}$ & $\begin{array}{l}\text { Indeks } \\
\text { Bias }\end{array}$ & $\begin{array}{c}\text { Volume } \\
\text { Murni } \\
(\mathbf{m l})\end{array}$ \\
\hline 2 & 3 & 5,4 & 12,663 & 1,3469 & 0,683 \\
\hline 3 & 3 & 10,7 & 14,522 & 1,3473 & 1,553 \\
\hline 4 & 3 & 8,5 & 15,427 & 1,3475 & 1,311 \\
\hline 2 & 6 & 8,0 & 13,065 & 1,3470 & 1,045 \\
\hline 3 & 6 & 12,3 & 16,030 & 1,3476 & 1,971 \\
\hline 4 & 6 & 9 & 12,512 & 1,3469 & 1,126 \\
\hline 2 & 9 & 5,4 & 14,271 & 1,3473 & 0,770 \\
\hline 3 & 9 & 12,5 & 20,996 & 1,3487 & 2,624 \\
\hline 4 & 9 & 5,2 & 16,380 & 1,3477 & 0,851 \\
\hline
\end{tabular}

\section{Kesimpulan}

Etanol dapat dihasilkan dari hasil tanaman, dalam penelitian ini yaitu Biji Cempedak.
Kombinasi perlakuan konsentrasi ragi dan lama fermentasi yang memberikan hasil terbaik pada penelitian ini adalah penambahan konsentrasi ragi sebanyak $9 \%$ dan lama fermentasi 3 hari, dimana volumenya adalah sebesar $12,5 \mathrm{ml} / \mathrm{kg}$ per bahan baku awal, dan densitas $0,962 \mathrm{~g} / \mathrm{ml}$.

\section{Daftar Pustaka}

[1] Ayu, Pembuatan Bioetanol dari Limbah Biji Cempedak Dari Biji Durian, Tugas Akhir, Politeknik Kimia Industri, Medan, 2013.

[2] Ardi, Wahyu Raditya, Pemurnian Etanol dari Tape Ubi Kayu (Manihot utilissima) (Kajian Suhu dan Lama Waktu Distilasi), Skripsi, Program Sarjana Fakultas Pertanian, Universitas Brawijaya, Malang, 2009.

[3] Donati, Gianni dan Paludetto, Renato, Scale Up of Chemical Reactors, Journal Catalysis Today. 34 : 483-485, 1997.

[4] Fitriana, Lila, Analisis Kadar Bioetanol Hasil Fermentasi Pati Sagu (Metroxylon sago) Asal Papua, Skripsi, Program Sarjana Fakultas Teknik, Universitas Negeri Papua, Jayapura, 2009.

[5] Geankoplis, C.J, Transport Process and Separation Process Principles, New Jersey: Prentice Hall, Fourth Edition, 2003.

[6] Hatta, Violet, Manfaat Kulit Durian Selezat Buahnya, Skripsi, Universitas Lampung, 2007.

[7] Humaidah, Nurlaili, Produktivitas Etanol menggunakan Teknik Immobilisasi Sel KKaraginan dalam Bioreaktor Paked Bed, Skripsi, Fakultas Teknologi Industri, Institut Teknologi Sepuluh November, Surabaya, 2010.

[8] International Atomic Energy Agency, Guidebook on Design, Construction and Operation of Pilot Plants for Uranium Ore Processing, Vienna : International Atomic Energy Agency, 1990.

[9] Komarayati, Sri dan Gusmailina, Prospek Bioetanol sebagai Pengganti Minyak Tanah, Pusat Penelitian dan Pengembangan Hasil Hutan, Bogor, 2010.

[10] Kurniawan, Roni; Juhanda,S; Syamsudin, Rusyad dan Lukman Moh. Alief, Pengaruh Jenis dan Kecepatan Pengaduk pada Fermentasi Etanol Secara Sinambung dalam Bioreaktor Tangki Berpengaduk Sel Tertambat, Skripsi, Program Sarjana Fakultas Teknik, Institut Teknologi Nasional, Bandung, 2011.

[11] Mahatmandi, Widhi F dan Minarni, Optimalisasi Olahan Buah Durian sebagai Alternatif dalam Usaha Agrowisata Durian, Jurnal Penerapan Teknologi dan 
Pembelajaran, 8 (1) : 21-26, 2010.

[12] Peraturan Pemerintah, Peraturan Pemerintah No. 5 Tahun 2006 tentang Kebijakan Energi Nasional, Jakarta, 2006.

[13] Perdana, D.A, Kajian Tekno Ekonomi Perancangan Proes Produksi Bioetanol dari Limbah Tanaman Jagung, Skripsi, Program Sarjana Fakultas Pertanian, Institut Pertanian Bogor, Bogor, 2011.

[14] Revitasari, Reviana, Pengaruh Konsentrasi Ragi dan Lama Fermentasi terhadap Perolehan Bioetanol dari Kulit Durian, Skripsi, Fakultas Teknik, Universitas Sumatera Utara, 2014.

[15] Richana, Nur, Bioetanol (Bahan Baku, Teknologi, Produksi dan Pengendalian Mutu), Bandung, Penerbit Nuansa, 2011. 